\title{
Grassroots responsible innovation initiatives in short food supply chains
}

\section{Introduction}

Increasing numbers of citizens and consumers look at non-intensive agricultural practices as alternatives to intensive farming and its impact on climate change. They specifically rethink the logistics of food provisioning to provide localized and smaller scale alternatives.

The impact of the globalized food system on climate is widely known. In 2008, a Greenpeace report identified western styles of food provisioning, and specifically intensive farming for global distribution, as one of the main issues that needed to be tackled in order to temper climate change and health hazards. In particular, agriculture-related greenhouse gas emissions are a major contributor to global warming, including both indirect emissions arising from agricultural practices (taking into consideration production, transport and use of agricultural fertilizers) and direct emissions from specific agricultural practices (for example, livestock and manure management). Added to this, the expansion of agriculture into uncultivated areas increases emissions from deforestation and land conversion (Bellarby et al. 2008: 1-26). Recently the debate has focussed on the effects of increased meat demand and of global food logistics. While the latter extends greenhouse gas emissions beyond the mere scope of agricultural production because of the impact of travel and transportation of goods and foods, the former necessitates more land to produce animal feed, and fossil fuels to produce and transport feed (Bellarby et al., 2008: 26-28).

Changing diet is only one of the ways in which these consumption patterns and provisioning styles are being rethought. While consuming less meat, for example, is a choice that can be pursued individually, shunning the commodity distribution chain that profits from and thus finances intensive farming as a global system requires more complex thinking and collective action. Styles of food provisioning are thus particularly relevant to the issue of sustainability. Short food supply chains can be considered an innovation challenge for contemporary societies - a challenge requiring counterepistemologies and re-training, including peer-to-peer lifelong re-education. Many new "worlds of food" have emerged and coexist (Morgan et al. 2006): 
some forms of community supported agriculture (CSA) involve a palette of new skills, from permaculture and composting (Abrahamson and Bertoni 2014) to gathering, exchanging and cooking local and seasonal food (Faigel and Sinfield 2017). Direct-to-customer organic farming is being experimented with according to various formulas, ranging from farmers' markets tothe French AMAPs (Associations pour le Maintien d'une Agriculture Paysanne). The Slow Food movement has inspired "convivia" and "slow cities" (Cittaslow). Various forms of animal-sharing and city farms have led to digital platforms and box delivery schemes.

Short food supply chains are thus reviewed in this chapter as responses to the agri-food system challenges that the book's editors take as their starting point, adding a critical overview of the idea of "responsible innovation" drawing on multidisciplinary literature (Hankins 2019). I propose that collective food procurement can be analysed as a form of grassroots innovation that enables consumers to take collective responsibility in the global food system. I illustrate this with two examples, considering their limits and potential.

Based on ethnographic research, my contribution has a regional focus. After a brief review of fieldwork observation of the local food movement in Massachusetts, USA (2012-2014), I focus on an Italian case study (2009-2011), GAS-gruppi di acquisto solidale or solidarity purchase groups -in the context of a multiform European local food movement. I view these as two examples of grassroots responsible innovation through short food supply chains.

In particular, I highlight GAS's relational and epistemological potential with respect to forging new partnerships and fostering knowledge circulation, and also compare them with similar phenomena studied by others (notably the Slow Cities movement studied by Sarah Pink). I conclude by discussing the comparative aspects that should be developed in a longer study and look at the pros and cons of grassroots groups as drivers of responsible innovation in food chains.

\section{A crisis of responsibility}

Sustainable food is the subject of numerous academic conferences, publications and academic programmes spanning engineering, urban planning, design and business schools. In fact, "the problem with sustainability is that as it becomes a universally accepted value, its meaning is becoming increasingly nebulous" (Ubois 2011: 4). In other words, as Krause and Sharma (2012) demonstrate ethnographically in the case of Amherst in Massachusetts, sustainability can be co-opted by various social groups with opposing interpretations and intentions to argue in favour of measures in the service "of the common good" as each sees it. "Instead of being a force for uniting disparate interests in the stewardship of a common heritage, sustainability appears to have become a lightning rod for old antagonisms, deepening the rifts that have existed for quite a while" (Krause and Sharma 2012: 640). Sustainability 
is thus an increasingly contested terrain. The very meaning of the term ranges from environmental stewardship to the search for technological fixes to the multiple challenges of climate change, demographic pressures and the inefficient and wasteful provisioning of energy and natural resources. However, such interpretations of sustainability are limited and are often contested. A "triple bottom line" (Henriques and Richardson 2004) approach claims that sustainability does not just have an environmental meaning but an economic one (an enterprise must not only avoid pollution but must make a profit) as well as a social meaning: our livelihoods and models of development must not only be economically viable and environmentally friendly but also socially equitable.

A variety of citizens' initiatives have expressed a need for sovereignty over matters of sustainability, and of food in particular. They not only request that their food is sustainable (as determined by others); they wish to take responsibility for it. Alternative agri-food networks, diverse models of community food economies, citizens' mobilization against agro-criminal networks and models for transition are among these initiatives. They provide opportunities to contextualize grassroots understandings of innovation, sustainability and responsibility on the basis of an in-depth comprehension of their cultural diversity in different historical and geographical contexts, which highlight cultural, class and gender differences as well as, sometimes, political and ethnic marginalization.

Sustainable innovation in food production - as applied, for instance, to genetically modified (GM) crops, animal cloning or land fertility crises - has so far been discussed using the conceptual framework of risk "assessment" and "management" of technological innovation. Finding universal normative criteria for responsibility in food innovation is, however, difficult if not impossible, as this implies a universal value framework that can inspire political action (politics, at its best, being a participatory deliberation of the goals of the polis, namely, of the community of citizens). Social studies of science and technology provide a critical method for analysing the assumptions in which debates - or the absence of debate - are cast (Jasanoff 2006; Levidow and Carr 2009).

Innovation in fields of bioethical scrutiny reflects the relationship between democracy and science in advanced societies. It is particularly important, then, to understand how techno-scientific issues (such as biodiversity, GMOs, hygiene, pest control, etc.) are not only configured within disciplinary discourses, but also appropriated in practice, since science and technology are political objects that permeate everyday life (Macnaghten 2016). Grassroots short food supply chains can be understood as efforts to offer alternatives to the current agri-food system - as expressions of responsible innovation.

The main idea behind grassroots responsible innovation is that this approach to sustainability goes beyond the idea of mere "product checking" and includes community development, social equity and respectful transactions. These innovations often focus on food for two reasons: first, because food production is one of the most unsustainable activities on the planet 
(including issues of energy provision, intellectual property and gross exploitation of humans, animals and natural resources); second, because it is often in the area of food provisioning that communities find the need, the capacity and the margins of action to rethink their participation in the economy. The following case studies show how alternative provisioning movement in Massachusetts and Lombardy focus differently on the relationship with local communities. Forms of provisioning activism (especially in the area of food, but also in those of commodities, energy and currency) range from the so-called solidarity economy in Italy to CSA schemes in the USA, and include many other actors and organizations. Here I will focus on solidarity purchase groups in Italy and the "local food movement" in Massachusetts as emerging dynamics in which the relationship between producers and consumers is being rethought in multiple, sometimes contradictory, ways. Do short supply chains transform lifestyles? Are these emerging economic circuits promoting environmental, economic and social resilience?

It of course depends on the context, the ideology and the actual practices that follow. On the one hand, the chapters in this book that address the sustainability challenges in food supply chains have an interdisciplinary perspective, and seek to clarify the added value of indepth qualitative research into short food supply chains. On the other hand, we may encounter different outlooks on responsibility, sustainability and innovation when we discuss these issues, not only in general and abstract terms but through the ethnographic observation of relevant local dynamics.

Food communities are particularly suited to the notion of innovation as"the ability to achieve the improbable" (Bassetti 2003), as ethnographic research proceeds from the complexity of local contexts rather than from general definitions. As opposed to an interpretation of innovation as a mere technology-fix, Bassetti's intuition is that innovation does not simply mean novelty but rather "something previously improbable, now made real" (Bassetti 2003). He further distinguishes between capital intensive innovation and poiesis intensive innovation. The latter forges new links between knowledge and agency, which bring into existence previously unknown objects, relations or situations. Innovation thus does not coincide with invention (which is often science and capital intensive), but with the ability to transform lifestyles.

In particular, poiesis intensive innovation refers to the cultural aspects of work practices, such as beauty and taste, logistics and design. Innovation is thus not seen as an individual creative act, but as a social process that permeates contexts and institutions and, in turn, depends on them.

Poiesis is thus not only the dimension of individual creativity, but the collective and practical capacity of rearranging existing resources in more meaningful ways. It is the dimension of aesthetic and moral appeal instead of mere economic rationality. For example, sustainable tourism, didactic applications of organic farming, culinary typicity, alternative food networks and eco-museums are all examples of private and public enterprises encouraging poiesis intensive innovation in marginal rural areas. Drawing on two personally 
conducted ethnographic case studies, I will argue that an ethnographic approach to the - often intertwined - ecological, economic and social issues implied in innovating the food system favours a focus on creative social experiments and can help us to investigate how innovation takes shape in some contexts, but not in others.

\section{Reinventing food chains: experiments in grassroots innovation}

My ethnographic observation focuses on Europe (Italy in particular) and the USA (Massachusetts in particular) in comparative perspective. I will argue that grassroots short food chains are an example of poiesis intensive innovation, which emerges through a spontaneous aggregation of concerned citizens - both producers and consumers. A rich constellation of grassroots movements are posing the question of food as a political object of risk perception and of collective deliberation, devising and organizing alternative food provisioning networks that value health standards, but also social and environmental sustainability in food production. From Slow Food to CSA, from Solidarity Purchase Groups (Gruppi di acquisto solidale or GAS) to Transition Towns, a collective and participatory response to the public perception of techno-scientific innovation and of sustainability is emerging.

In the USA, CSA is now a well-established and commercially viable alternative to the consolidated food industry, especially in urban areas on both coasts. However, working at the high end of a dramatically divided ruralsocial scenario (dominated by so-called million-dollar farms and very cheap processed food), CSA can more easily speak to affluent sectors of society than can re-engineering social cohesion in local communities, urban health in food deserts and food sustainability in the agri-food system at large. Additionally, CSA is largely producer-driven, a sustainable business model for small or new farmers who wish to target a niche, high-end sector of American urbanites.

The French AMAPs work as pre-paid contracts for the delivery of crops, very much like CSA. Consumers take on the risk of cultivation by paying for crops in advance and thus shield local farmers from risks and bankruptcy; they may also actually participate in crop preparation and harvesting in the field thus developing a more communitarian feel of attachment to the farm and the farmer, as well as requiring not just money but also time as a (possibly even more precious) form of investment. However, in Europe multiple forms of consumer-driven initiatives have also emerged on a local scale. For example, in Germany the Solidarity Agriculture movement works against farming turning into agribusiness by developing similar partnerships with local farmers.

While solidarity economy networks can be considered as "social networks" involving mainly consumers in networks of self-help, CSA is increasingly seen as a successful business model for neo-rural entrepreneurs (Henderson and Van En 2007). What constructive scenarios do these movements provide 
for rethinking the role of technology and capital in food production? How do they convey expectations of responsibility in innovation? Is responsible behavior in food production and provisioning by definition averse to techno-scientific innovation?

\section{The Boston local food movement}

During the period August 2011 to May 2014 I worked in Boston, Massachusetts and had the opportunity to observe and participate in the local food movement that was gaining momentum in the urban area and, indeed, state-wide. This was by way of personal participation in multiple CSA schemes over three years, by attending public events and festivals focused on sustainable food in Boston, Cambridge, Somerville, Worcester and Springfield, by teaching and supervising research students on Boston University's Master of Liberal Arts in Gastronomy and by attending seminars and webinars on the "new economy". The latter included training courses on how to set up a CSA farm, networking events for young entrepreneurs organized by co-working spaces such as the WorkBar in Cambridge, Massachusetts and the FoodLoft in Boston and conferences organized by the Massachusetts state government to encourage "sharing economies" including, but not limited to, food supply. Still recovering from a dramatic economic downturn due to the financial crisis of 2008, governmental, non-governmental and private initiatives were visibly investing - among other "new economy" initiatives - in face-to-face education around food entrepreneurship and technology, such as the Food \& Entrepreneurship Meetup in Boston.

As a result, a self-defined "food community" - or a "local food movement" as often referred to at public events - emerged in Boston, encompassing a very wide and diverse range of interests, some of which did not specifically address each other's concerns (if any) with sustainability, some being more focussed on creating new entrepreneurial opportunities, while others addressed equity and social justice through access to healthy and affordable food. From encouraging start-up companies selling organic snacks, to CSA schemes offering sliding-scale shares, to increased access to fresh food for less wealthy families and non-governmental organizations (NGOs) openly advocating "food justice", the range of activities and statements was indeed very wide (Loh and Agyeman 2017). Naturally Boston, the cradle of Massachusetts Institute of Technology and Harvard, offers a rich network of mentors, investors, incubators, "accelerators", publishers and working spaces that can tap into the lively political and cultural debates, as well as high incomes in the area, to experiment with short food chains or with sustainable food technology. Examples included Cuppow, a patented drinking lid for preserving jars; Boston Organics, a local food delivery scheme; FoodEx, a sustainable food logistics hub; and Bootstrap Compost, a composting agency offering to pick up food scraps and deliver back compost for gardening. The shared philosophy behind these entrepreneurial efforts is that something 
creative and lucrative can be done to respond to some of the global food challenges such as food waste (about one-third of the food produced across the world is lost or wasted; see FAO 2013). The recipe was intervening in innovative and tech-driven ways in the production, supply and distribution networks of current food systems, thus impacting urban lifestyles.

The plethora of apps, products, logistics providers and distribution companies that ensue, however, hardly speaks to another pressing problem for contemporary American society: namely, the shocking number of undernourished children and families, the rising epidemic of type- 2 diabetes and the large food deserts in which impoverished households without a car and the necessary income cannot find the fresh fruit and vegetables they need to stay healthy (Pringle 2013). Potentially, CSA may be able to respond to this need by ensuring shorter local food chains and putting farmers in touch with the food needs of their surrounding communities. However, this would require that the farmer is a smallholder living in the proximity of these "eaters", producing a diverse range of edible food. Consolidated agriculture in globalized agri-food systems, however, works hectares and hectares of industrial crop-monocultures (typically corn for the food processing industry, soy and alfalfa grass for the production of animal fodder). Additionally, the market logics of demand and supply for fresh, quality food does not necessarily set up a viable conduit between small farmers and malnourished $\begin{array}{llllllllllll}\text { c } & o & m & m & u & n & i & t & i & e & s\end{array}$

During the three years I lived in Boston, I became a member of three different CSA schemes, one rather large serving two different pick-up locations in Boston, one much smaller mainly serving central Massachusetts but aiming to expand to the Boston area in partnership with a bike-delivery worker-owned cooperative and a box-delivery scheme. I also attended farmers' markets both in my immediate neighbourhood and further afield in different locations in Massachusetts. The pressure on farmers was to keep their clients; for example, they introduced loyalty programmes and text message notifications, newsletters, mailing lists, etc. As explained to budding CSA farmers in the webinar organized by Small Farm Central in March 2014,

there's just more competition for a CSA dollar, and you just have more options than ever to get high quality food. Even our, you know, local ... local grocery store ... so we're in Pittsburgh, Pennsylvania, I know our ... just regular local grocery stores have great produce now. So ... there's delivery services, and there's co-ops, there's so many options for people to get really high quality food, so there's more competition for that eating dollar.

(Small Farm Central 2014)

CSA is a marketing device to secure a unique connection between a farmer and a customer for those who can afford it. The customer will subscribe to harvest "shares" in advance - usually for a season but possibly for the 
whole year - so that a higher level of continuity and trust can be established than by occasionally attending farmers' markets. This is the strongest way to support a small farm and it is usually initiated by the farmer through a marketing campaign: distributing brochures, setting up and maintaining a website and email notifications, inviting trusted customers to "potlucks" and events such as apple-picking and hay-making feasts on the farm's premises. As I had occasion to witness, these events are family-oriented, festive and convivial, but strictly based on a commercial relationship between the individual customer-family and the farmer or farm enterprise. Just like visiting a fun fair, kids were entertained by farm workers, videoprojections would celebrate the latest projects or farm enlargements, hayrides would take us into the fields where some explanations would be given on seasonality and types of cultivation; apples would perhaps be picked. However, limited and superficial interaction ensued - as appropriate for a "community" that materializes in the space of a fleeting, however principled and well-meaning,ncommercial interaction.

Both producers and consumers are aware of the limitations to realizing CSA's potential to reach more disenfranchised sectors of American society.

Facilitating schemes, to be fair, were on the rise, including some Massachusetts cooperative credit banks offering loans to students so that they could afford to join a local CSA instead of eating junk foods. Several CSA schemes offered "sliding-scale shares", where one could volunteer to pay a higher price based on self-assessed income so that someone with less income could pay a lower share. However, participating in a CSA scheme remained, on the whole, a costly affair: from the US $\$ 2,000$ requested for a yearly share in local fruit and vegetables in Boston, to Cape Cod Fish Share schemes to ensure that the New England fishing tradition remains viable and sustainable for both the remaining fishermen and the remaining fish, to the slightly lower prices offered by other farmshare options, there was a clear sense of the privilege enjoyed by those who participated.

\section{Consumer-driven short food chains in Italy}

In Italy, solidarity purchase groups (gruppi di acquisto solidale or GAS) have 34 emerged slowly since the 1990s as networks of consumers who work in close collaboration with individual producers (or sometimes cooperatives) to procure food and other items as far as possible directly, on a local basis and in a sustainable manner. By seeking a direct relationship with producers and cooperatives, these groups move beyond ethical consumption towards engaged and collective forms of procurement. The sociologist Michele

Micheletti (2003) has defined political consumerism as "individualised collective action", namely, an individual's personal involvement in a wider movement of critical consumption by way of boycotting or buycotting.

Micheletti argues that critical consumption networks provide ways of assuming individual responsibility by moving beyond the role of mere consumer, 
triggering new lifestyles and thus turning food into a political object. Furthermore, with GAS food becomes political because consumers organise themselves as collectives, in order to exercise a form of political agency in the economic system.

My case study is based on two years when I participated in a GAS collective in Bergamo in northern Italy, and on my work as a delegate of my group in a network of 32 GAS in the province of Bergamo (an area of about one million inhabitants comparable to that of Greater Boston) in the period spanning 2009 to 2011. GAS adhere to a philosophy of direct relationship with their providers, who they call "producers" to indicate that they wish to procure their food directly from growers. Their National Charter promotes "respect for the environment and solidarity between the members of the group, the traders and the producers" (Gruppi di Acquisto Solidale 1999). They are groups of, on average, 20 to 40 families who directly manage the logistics of collective purchase: this work is largely based on voluntary and informal self-organization.

In practice, GAS members convene periodically (usually once a month, though this varies greatly according to local preferences and to group size) to organize and share the tasks of bulk-buying from trusted producers. These may be local organic farmers or breeders (for vegetables, fruit and meat), dairies for milk and cheese, or preferably cooperative or farmers' consortia as processers of oil and basic foodstuffs such as pasta, sauces and fruit juices. The national network of GAS, Retegas, estimates that about 100,000 people practice this method in Italy alone. Their collective practices include assessing the producers, organizing on-site visits and holding social events. In many cases, participating in a group means being socialized into home bread making, cherry picking, grape harvesting, chestnut picking, etc. I propose to look at all these practices as "cross-cutting counter-epistemologies" (Grasseni 2013), namely, as overlapping practices and routines that develop new competences. These are notably not necessarily farming skills, but rather logistics and accounting; reciprocity and leadership within the group; information processing and communication about organic certification and food labelling.

Among the examples of responsible innovation adopted by GAS are the capacity to "network up" among several groups. These larger networks may contribute to very local and specific forms of responsible innovation - for example, engaging local administrations to provide them with a public space for managing orders or lobbying for the provisioning of organic food to school canteens. "Districts and networks of solidarity economies" - DES (distrettidi economia solidale) and RES (reti di economia solidale) - are examples of responsible innovation through which networks of GAS establish alliances with other "alternative" socio-economic actors such as Fair Trade shops, ethical banks, responsible tourism agencies or environmental associations to develop specific projects. For example one such alliance promoted the use of local wheat cultivars to make bread. GAS are a pivotal point in these short chains as they provide the necessary economic guarantee that the product will have buyers. 
Across these networks, food works as a social aggregator through practice and knowledge. These very localized and concrete, day-to-day practices have the ambition of trying to respond to global issues such as fair price and food sovereignty, or that of moral solidarity between producers and consumers.

GAS implement a sort of practical moral philosophy: responsible behaviour in food provisioning is not about making big normative choices, but rather about choosing an innovative course of action with soft technologies and a laborious relational framework which may change one's lifestyle - a poiesis-intensive form of innovation.

The range of examples of experiments with food as a form of responsible 1innovation is in fact widespread and diverse. Sarah Pink describes the similarities between the philosophy of the Slow Food movement and that of the

Cittaslow (slow city) network. Both wish to engage their members in "educational" projects in a broad sense: Slow Food is interested in taste education, Cittaslow in quality living. The Cittaslow charter includes measures such as places for people to "sit down and rest, not just in town centres" or plans to "plant sweet smelling or environmentenhancing plants in public and private gardens" (Pink 2009). This example works at a different scale than the entirely spontaneous networks of consumer-citizens in GAS, as "Cittàslow inevitably begins life as a topdown process, in that it is necessarily led by the town council" (Pink 2009). Cittaslow activists are not grassroots militants but rather exercise their influence through participating in governance: Pink sees Cittaslow as "working as a form of persuasion by example" (Pink 2009). Sustainable local economy is, for instance, one target of Cittaslow's policies, and Pink mentions the rationale of

Cittaslow administrators in acting against encroaching global supermarket chains. Cittaslow does not campaign directly against Tesco or other chains, but rather invests in creating closer links between producers and consumers, such as through farmers' markets. In contrast, GAS get together to buy directly from producers, thus promoting knowledge of their territory and of its seasonality. 31

For both, the aversion to supermarkets is motivated by the correlated disappearance of small shops for local customers (especially elderly people with no car), with the effect of driving most economic transactions out of historical town centres to purpose-built shopping malls. Additionally, small producers are often bound to distribution chains by contracts that set very low prices while binding them to ensuring fixed amounts of products in all seasons. This guarantees producers that their produce is going to be bought, but it also drains it, at cheap prices, from local markets where it could be sold for more during the high season. This kind of double-bind with chain distributors has to be taken into consideration when proposing alternative solutions such as farmers' markets. If new social partnerships are to support regional economies, the governance of these processes must be coupled with grassroots forms of responsible innovation. The contribution of the GAS movement in Italy seems precisely to be that it has introduced new forms of engagement (Forno 
and Graziano 2014), including practices that can "trickle upwards" into the institutional and administrative fabric.

\section{Conclusion}

A wide range of models of sustainable food production and consumption are being experimented with, from high-tech, capital intensive entrepreneurship to poiesis-intensive forms of consumer self-organization in collective food procurement networks. I considered grassroots short food supply chains as possible examples of responsible innovation as they re-invent basic, everyday, universal practices such as that of food procurement in innovative ways. These strategies, however novel they may look, should be considered against their diverse socioeconomic backgrounds and the political experiences that have preceded them. CSA schemes are, in a sense, contemporary re-editions of initiatives that started in the 1960s and 1970s with the first American consumer cooperatives. However, scholarship on alternative agri-food networks has highlighted that these initiatives often focus on quality and sustainability, and less on social inclusion and food justice - namely, access to resources for underprivileged groups (Mares 2014; Luetchford 2016; Alkon and Guthman 2017).

In Italy, with active political support, especially from left-wing parties, some of these initiatives have developed into nationwide supermarket chains such as Coop, a large distribution "cooperative". Slow Food - often critiqued for being elitist in its price-blind pursuit of quality - stems from Arcigola, the ex-Communist after-work association that offered popular cultural activities in the spheres of music, gastronomy, excursions, etc. GAS emerged as a form of consumer self-organization that preceded the widespread crisis in household incomes and food consumption in Italy. There is no obvious connection between the development of the GAS networks in Italy and the economic crisis that began in 2008, became particularly intense in 2011, and peaked during 2012-2013. However, during the crisis years GAS began to attract consistent attention from the media and even political parties, as they seemed to represent a bottom-up form of grassroots innovation in the name of solidarity and resilience. It is, in any case, mostly white, middle-aged, middle-class people who can afford the money, and especially the time, to make selfconscious choices about their diet and food procurement practices.

Community participation takes varying forms according to the dominant discourse in the respective contexts. While innovative entrepreneurship is invoked in the Boston area as part of a local thriving knowledge economy, Italian consumers mobilize strategies of self-rediscovery as communities of heritage, of conviviality and of neighbourhood, through novel readings of local landscapes and the re-evaluation of their agricultural vocation vis-à-vis expanding supermarket chains. This is particularly apparent in the small and medium towns adhering to Cittaslow, where the administrative and economic fabric of society experiments with food reinvention through a heritage framework (Grasseni 2017). These processes include the rise of new types of 
partnerships involving producers and consumers, administrators and citizens in local practices of economic and institutional co-production (such as Cittaslow or so-called districts of solidarity economy). Their analysis introduces an idiosyncratic variety to the debate about responsible innovation, which requires ethnographic observation and the cultural study of contexts to appreciate how differently ideas of responsibility, sustainability and innovation actually synergize within localized discourse and the practices of citizenship, trust and knowledge

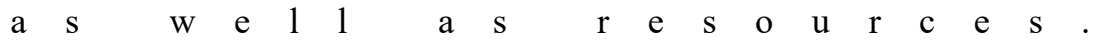

In a comparative perspective, the limits and potential of each of these phenomena become evident. Alternative food networks still have to demonstrate a tangible impact upon local economies and improvement in sustainable lifestyles, while they are usually voluntary-based, timeconsuming modes of engagement. They have so far instead showed a great capacity for self- organization and for implementing selforganized forms of lifelong education in food production and network management. Precisely because of their successful but socially particular proliferation, it is worth teasing out the strategies, motivations and critical points they share with other movements and initiatives. In this chapter, I proposed that an ethnographic insight into responsible innovation can assist an understanding of the diverse modalities and added value of localizing agri-food systems. Short food supply chains disseminate responsible innovation in the form of new partnerships, practices and networks -for example, circuits of peer-to-peer help or co-produced solutions to logistics, management and organization. Though not originating from the economic crisis, theses type of social networks facilitate the application of innovative alternatives in new, challenging contexts, also using the economic crisis to propose pathways and lifestyles that focus on solidarity and the environment as a common good.

\author{
Acknowledgement \\ The project upon which this chapter is based received funding from the \\ European Research Council under the European Union's Horizon 2020 research \\ and innovation programme (grant agreement No. 724151)
}

\title{
References
}

Abrahamson, S. and Bertoni, F. (2014). Compost Politics: Experimenting with Togetherness in Vermicomposting. Environmental Humanities 4(1): 125-148.

Alkon, A. and Guthman, J. (2017). The New Food Activism: Opposition, Cooperation, and Collective Action. Berkeley, CA: University of California Press. 
Bassetti, P. 2003. Innovation, Social Risk and Political Responsibility. Lecture presented at the London School of Economics, 14 May 2003. Available at:

www.fondazionebassetti.org/en/pages/2009/04/innovation_social_risk_and_pol.html (accessed 4 March 2017).

Bellarby, J., Foereid, B., Hastings, A. and Smith, P. (2008). Cool farming: Climate impacts of agriculture and mitigation potential. Greenpeace International.

Faigel, J. and Sinfield. J.V. (2017). Scaling Impact: Equity, Access, and Opportunity in Boston's Regional Food Economy. Social Innovations Journal 41, 4 December 2017. Available at:

www.socialinnovationsjournal.org/editions/issue-41/75- disruptiveinnovations/2680-scaling-impact-equityaccess-and-opportunity-in-boston-s-regionalfood-economy (accessed 8 May 2018).

FAO (2013). Food wastage footprint: Impacts on natural resources. Summary report. Available at: www.fao.org/docrep/018/i3347e/i3347e.pdf (accessed 21 August 2018).

Forno, F. and Graziano, P. (2014). Sustainable Community Movement Organizations. Journal of Consumer Culture 14(2): 139-157.

Grasseni, C. (2013). Beyond Alternative Food Networks. Italy's Solidarity Purchase Groups. London:

Bloomsbury.Grasseni, C. (2017). The Heritage Arena: Reinventing Cheese in the Italian Alps. New York:

Berghahn Books.

Gruppi di Acquisto Solidale (1999). Documento base dei GAS. Un modo diverso di fare la spesa. Available at: www.retegas.org/upload/dl/doc/GASDocumentoBase. PDF (accessed 4 March 2017).

Hankins, J. (2019). Grassroots Case Studies in Poiesis Intensive Responsible Innovation. In: R. von

Schomberg and J. Hankins (eds.), The Handbook of Responsible Innovation: A Global Resource. London:

Edward Elgar Publishing.

Henderson, E. and Van En, R. (2007). Sharing the Harvest: A Citizen's Guide to Community Supported Agriculture. Burlington, VT: Chelsea Green Publishing.

Henriques, A. and Richardson, J. (eds.) (2004). The Triple Bottom Line: Does It All Add Up? Abingdon, UK: Earthscan.

Jasanoff, S. (2006). States of Knowledge: The Co-Production of Science and the Social Order. London: Routledge.

Krause, E. and Sharma, A. (2012). Sustainability "Wars" in a New England Town. Futures 44: 631-641.

Levidow, L. and Carr, S. (2009). GM Food on Trial: Testing European Democracy. London: Routledge.

Loh, P. and Agyeman, J. (2017). Boston's Emerging

Food Solidarity Economy. In: A. Alkon and J. Guthman (eds.), The New Food Activism. Berkeley, CA: University of California Press, pp. 257-283.

Luetchford, P. (2016). Ethical Consumption: The Moralities and Politics of Food. In: J. Klein and J. Watson (eds.), Anthropology and Food. A Handbook. London: Bloomsbury, pp. 387-405.

Macnaghten, P. (2016). Responsible Innovation and the Reshaping of Existing Technological Trajectories: The Hard Case of Genetically Modified Crops. Journal of Responsible Innovation 3(3): 282-289.

Mares, T. (2014). Engaging Latino Immigrants in Seattle Food Activism. In: V. Siniscalchi and C. Counihan (eds.), Food Activism: Agency, Democracy, and Economy. London: Bloomsbury, pp. 31-46.

Micheletti, M. (2003). Political Virtue and Shopping. Individuals, Consumerism and Collective Action. New York: Palgrave Macmillan.

Mol, A. (2009). Good Taste. The Embodied Normativity of the Consumer-Citizen. Journal of Cultural Economy 2(3): 269-283.

Morgan, K., Marsden, T. and Murdoch, J. (2006). Worlds of Food. Place, Power and Provenance in the Food Chain. Oxford: Oxford University Press.

Pink, S. (2009). Urban Social Movements and Small Places. Slow Cities as Sites of Activism. City 13(4):

451-465.

Pringle, P. (ed.) (2013). A Place at the Table: The Crisis of 49 Million Hungry Americans and How to Solve It. New York: Participant Media and Public Affairs.

Small Farm Central (2014). Webinar organized by Small Farm Central on community supported agriculture, 6 March 2014.

Ubois, J. (2011). Responsible innovation/sustainable innovation. Fondazione Giannino Bassetti. Available at: http://issuu.com/fondazionebassetti/docs/jeff-innovation-aaa-2010-2 (accessed 21 August 2018). 
